\title{
Assessing Genetic Diversity Cocoa (Theobroma cacao L.) Collection Resistant to Cocoa Pod Borer Using Simple Sequence Repeat Markers
}

\author{
Analisis Keragaman Genetik Koleksi Kakao (Theobroma cacao L.) \\ Tahan Hama Penggerek Buah Kakao dengan Pemarka SSR
}

\author{
Agung Wahyu Susilo ${ }^{\left.1^{*}\right)}$, Dapeng Zhang $^{2)}$, and Lambert Motilal ${ }^{3)}$ \\ ${ }^{1)}$ Pusat Penelitian Kopi dan Kakao Indonesia, Jl. PB. Sudirman No. 90, Jember, Indonesia \\ ${ }^{2}$ USDA ARS Sustainable Perennial Crop Laboratory 10300 Baltimore Avenue Bldg. 001 Beltsville Maryland \\ ${ }^{3}$ Cocoa Research Unit, the University of the West Indies St. Augustine, Trinidad \\ *) Alamat penulis (corresponding author): soesiloiccri@yahoo.com \\ Naskah diterima (received) 3 Januari 2013, disetujui (accepted) 8 Maret 2013
}

\begin{abstract}
Breeding for cocoa pod borer (CPB) resistance on cocoa was initiated by selecting the resistant genotypes through cocoa farm in the endemic area. For breeding purpose the collected genotypes should be assessed for their diversity in constructing appropriate mating design. This research has objective to assess genetic diversity of the exploratory collection using DNA fingerprinting. The tested clones were 25 exploratory collections compared to the references of seven international clones from International Cocoa Genebanks, Trinidad and 12 national clones. DNA of the tested clones was sequenced using 15 SSR markers at Sustainable Perennial Crop Laboratory of Beltsville Agriculture Research Center. Data of fingerprinting were analyzed using GenAlEx program to perform number of alleles, observed heterozygosity (Ho), expected heterozygosity ( $\mathrm{He})$ and genetic distance. The tested clones performed high genetic diversity with the number of alleles was 98 (6.53 per locus) compared to the national clones and international clones were 95 (6.33 per locus) and 86 (5.73 per locus), respectively. The observed heterozygosity of the tested clones $(\mathrm{Ho}=0.63)$ was higher than national clones $(\mathrm{Ho}=0.60)$ and international clones $(\mathrm{Ho}=0.49)$ then supported by the expected heterozygosity $(\mathrm{He})$ of the tested clones $(\mathrm{He}=0.71)$ also high in equal value with international clones $(\mathrm{He}=0.74)$. Cluster analysis grouped the tested clones to three main genetic groups, namely Trinitario, Forastero and unidentified group. The CPB-resistant clones of ARDACIAR 10 and KW 397 were clustered in different group that indicate a far distance of their genetic background.
\end{abstract}

Key words: Genetic diversity, cocoa, CPB resistance, simple sequence repeat marker.

\begin{abstract}
Abstrak
Pemuliaan ketahanan terhadap hama penggerek buah kakao (PBK) telah diawali dengan seleksi genotipe tahan hama PBK di daerah endemik serangan. Untuk tujuan pemuliaan diperlukan informasi mengenai keragaman genetik materi koleksi. Penelitian ini bertujuan melakukan analisis keragaman genetik klon-klon hasil eksplorasi ketahanan PBK berdasarkan analisis sidik jari DNA. Materi percobaan adalah 25 klon kakao hasil eksplorasi, 7 klon koleksi internasional asal International Cocoa Genebanks, Trinidad dan 12 klon koleksi
\end{abstract}


nasional. DNA klon-klon materi percobaan selanjutnya dianalisis berdasarkan metode simple sequence repeat (SSR) menggunakan 15 primer di Laboratorium Sustainable Perennial Crop, Beltsville Agriculture Research Center. Analisis data menggunakan program GenAlEx untuk mengetahui parameter jumlah allel, heterozygositas teramati (Ho), heterozygositas harapan (He), dan jarak genetik. Hasil analisis menunjukkan bahwa klon-klon koleksi ketahanan PBK memiliki keragaman genetik yang tinggi berdasarkan jumlah allel yang terdeteksi sebanyak 98 allel (6,53 per lokus) dibandingkan jumlah allel klon nasional dan klon internasional, masing-masing sebesar 86 (5,73 per lokus) dan 95 (6,33 per lokus). Nilai heterozygositas teramati (Ho) klon-klon koleksi tahan PBK $(0,63)$ juga lebih tinggi dibandingkan klon nasional $(0,60)$ dan klon internasional $(0,49)$ kemudian didukung oleh nilai heterozygositas harapan $(\mathrm{He}=0,71)$ yang sebanding dengan nilai klon internasional $(\mathrm{He}=0,74)$. Hasil pengelompokan berdasarkan jarak genetik bahwa klon-klon koleksi tahan PBK terbagi dalam 3 kelompok genetik, yaitu Trinitario, Forastero, dan kelompok belum teridentifikasi. Klon-klon terseleksi tahan PBK, ARDACIAR 10 dan KW 397 termasuk dalam kelompok genetik yang berbeda.

Kata kunci: Keragaan genetik, kakao, ketahanan hama PBK, pemarka SSR.

\section{BACKGROUND}

Breeding for cocoa pod borer (CPB) resistance in Indonesia was carried out intensively during last ten years by exploring and selecting resistant genotypes on-farm at the CPB-endemic area. Success stories on-farm selection (Pokou et al., 2009; Opoku et al., 2009) inspiring this approach enables to be implemented on selecting CPB-resistant genotypes. Gamete segregation during fertilization between heterozygous genotypes of cocoa clones possible constructing genetic recombination among hybrid progenies that would be a number of the recombinant genotypes resistant to CPB. The opportunity to select CPB-resistant genotypes on farm was endorsed by so high variation of genetic materials through cocoa farms as most of the trees derived from seedlings. Since early 1980's cocoa area has increased rapidly till cover more than one million hectares as the impact of government policy on cocoa development (Ditjenbun, 2008). This potency on genetic variability has been explored to find out CPB-resistant genotypes that some promising clones which resistant to $\mathrm{CPB}$ were selected (Susilo et al., 2009, 2012). The exploratory of selected genotypes pioneer breeding materials which should be conserved and utilized for accelerating breeding program.

The effectiveness on utilization of the collected CPB-resistant genotypes would depend on the information of genetic background of the collection that crossing can be properly developed between parental clones of the group with their distant genetic background to execute hybrid vigour. Cocoa was traditionally grouped based on morphological characteristics into three main categories, namely Criollo, Forastero \& Trinitario (van Hall, 1914). However after long-time cultivated since $16^{\text {th }}$ century (Urquhart, 1961), cocoa diversity now has developed into various genetic background as cocoa traditionally is propagated using seeds derived from the open-pollinated trees that the diversity improve simultaneously. Motamayor et al. (2008) confirmed the diversity using molecular marker by which 
cocoa collection was classified into 10 genetic groups, namely Marañon, Curaray, Criollo, Iquitos, Nanay, Contamana, Amelonado, Purús, Nacional and Guiana. The new groups point out that on-farm selection enable to improve genetic diversity on cocoa. This phenomenon would also occur in Indonesia cocoa collections which were collected through on-farm selection with no information concerning their genetic background.

Breeding for CPB resistance on cocoa in Indonesia was initiated by selecting resistant clones of the collected genotypes (Susilo et al., 2012). The collection performed their various resistance which were classified into five groups of resistance namely resistant, moderate resistant, moderate susceptible, susceptible and highly susceptible to indicate the variability of CPB resistance. For breeding purpose, the phenotypic classifications would be more beneficial when supported by the information concerning genetic background of the collection. By using molecular marker, the diversity of collected genotypes was assessed to characterize genetic background of CPBresistant genotypes to support breeding program. This paper presents data of the analysis of the collected genotypes to enable in differentiating their genetic groups.

\section{MATERIALS AND METHODS}

A total of 25 cocoa collections which are mainly exploratory collected through cocoa farm in Indonesia described in Susilo et al. (2012) were used in this experiment. These clones were collected at Kaliwining Experimental Station of Indonesian Coffee and Cocoa Research Institute (ICCRI). Genetic references of 12 accessions of national collection and 7 accessions of international collection from International
Cocoa Genebanks Trinidad (ICG, T), the University of West Indies Trinidad were also included. For this experiment, young leaves of collected genotypes were air-dried then sent to Sustainable Perennial Crop Laboratory (SPCL) at Beltsville Agricultural Research Center in Maryland United State of America (USA) for genotyping.

\section{SSR Genotyping}

DNA was extracted following the instruction of DNeasy Plant System (Qiagen Inc.) with modification according to Zhang et al. (2006) to reduce phenol content. For SSR analysis, 15 primers were selected, namely mTcCIR7, mTcCIR18, mTcCIR40, mTcCIR22, mTcCIR24, mTcCIR15, mTcCIR1, mTcCIR33, mTcCIR60, mTcCIR11, mTcCIR12, mTcCIR26, mTcCIR6, mTcCIR8 and mTcCIR37 which refer to Lanaud et al. (1999); Risterucci et al. (2000) and Saunders et al. (2004). The primers were syntetized by Proligo (Boulder, CO) in which the forward primer (5'-labeled) colored with WellRED fluorescent (Beckman Coulter, Inc., Fullerton, CA).

Analysis of polyacrilamic chain reaction (PCR) followed the procedure reported by Motilal et al. (2009) using reaction mix consited of Magnesium $2.5 \mathrm{mM}$, MPP $0.35 \mu \mathrm{M}$, total dNTP $0.2 \mathrm{mM}$, DNA polymerase $0.25 \mathrm{U}$. The temperature for annealing was $51^{\circ} \mathrm{C}$ for all the primers. The amplified PCR products were seperated by capillary electrophoresis described by Saunders et al. (2004) using a CEQTM8000 machine then the DNA fragments automatically were detected by CEQTM8000 Genetic Analysis System. Data analysis were performed using CEQTM 8000 binning wizard software (CEQTM8000 software version 9.0, Beckman Coulter Inc.). 


\section{Data Analysis}

Data of amplified DNA were analyzed using Genetic Analysis in Excel (GenAlEX) ver. 6.1 program (Peakall \& Smouse, 2006) to identify heterozygosity of locus, number of alleles and genetic distance among tested clones. Data of genetic distance were converted to biplot graph using Principal Coordinate Analysis (PCo). The dendogram of UPGMA (Unpairwise Group Mean Average) was also performed using Statistica program to visualize the genetic groups.

\section{RESULTS AND DISCUSSION}

The results on DNA sequencing performed that all of the microsatellite loci showed high level of polymorphism within the tested clones and the references. Figure 1 shows an example data of the amplified DNA of the tested clones performed using CEQ 8000 machine. The number of alleles detected within tested clones were 98 (6.53 per locus which were) higher than of the international clones and of the national clones were 95 (6.33 per locus) and 86 (5.73 per locus), respectively (Table 1 ). The number of alleles within the tested clones and national clones was relatively less than the number of alleles detected within CATIE collection was 231 alleles (Zhang et al., 2008). Comparison of the allele number indicated high contribution of the tested clones and national clones to internasional diversity respectively $42.42 \%$ and $37.22 \%$. The parameter of expected heterozygosity (He) also performed high diversity of the

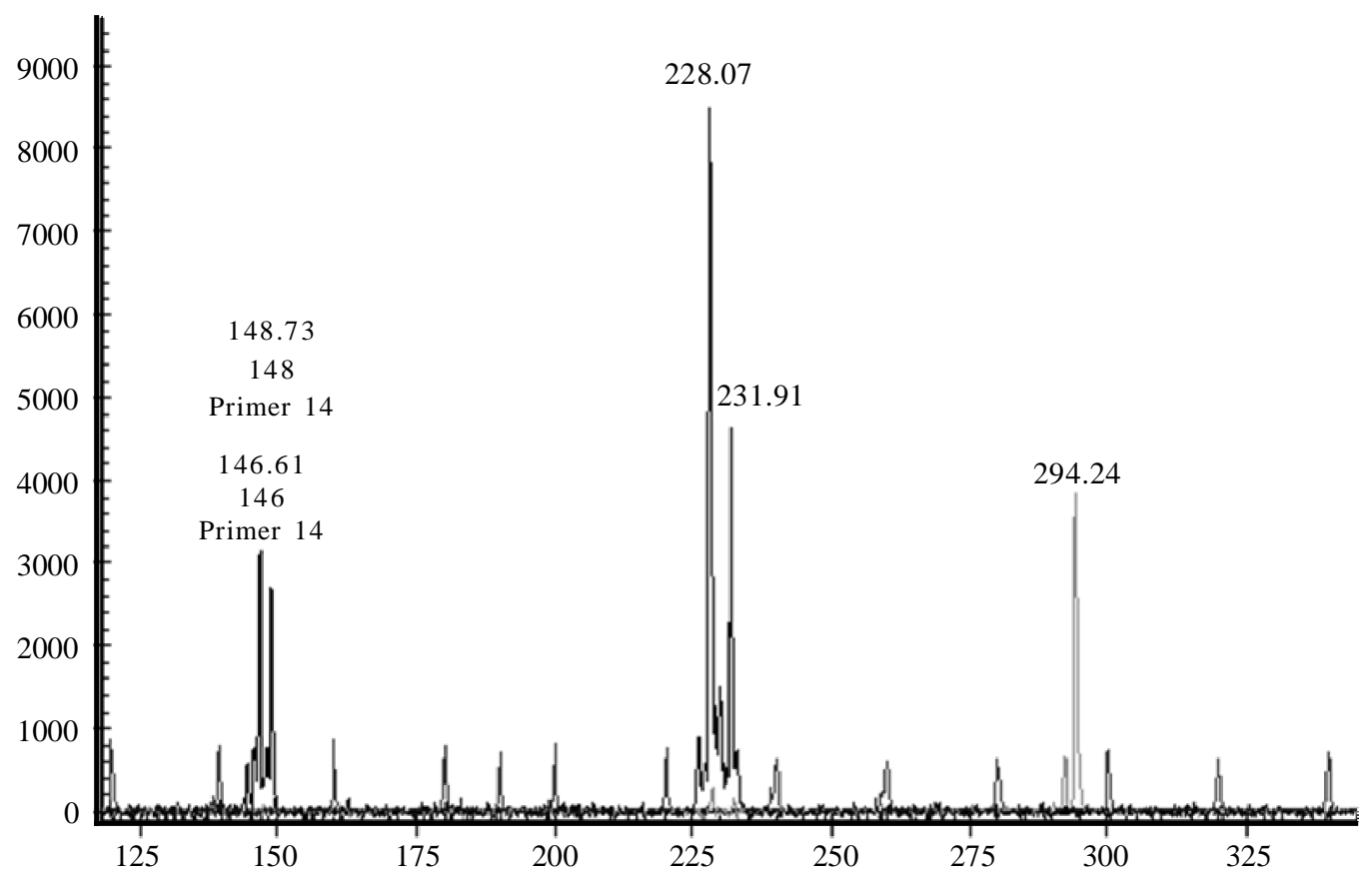

Figure 1. Profile of DNA fragment one of the tested clones (KW 570) by using SSR technique at three different loci of mTcCIR37 heterozygous for allele 146 and 148, mTcCIR6 heterozygous for allele 228 and 232, mTcCIR8 homozygous for allele 294.

Gambar 1. Profil fragmen DNA salah satu klon materi percobaan (KW 570) hasil analisis SSR pada tiga lokus yang berbeda, mTcCIR37, heterosigot untuk allel 146 dan 148, mTcCIR6 heterosigot untuk allel 228 dan 232, mTcCIR8 homosigot untuk allel 294. 
Table 1. Genetic parameters from sequencing result of DNA fingerprinting analysis on tested clones by using 15 SSR primers Tabel 1. Nilai parameter genetik hasil analisis sidik jari DNA klon-klon materi percobaan menggunakan 15 pemarka SSR

\begin{tabular}{|c|c|c|c|c|c|c|c|c|c|}
\hline \multirow{2}{*}{$\begin{array}{l}\text { Locus } \\
\text { Lokus }\end{array}$} & \multicolumn{3}{|c|}{$\begin{array}{l}\text { International clones } \\
\text { Klon internasional }\end{array}$} & \multicolumn{3}{|c|}{$\begin{array}{l}\text { National clones } \\
\text { Klon nasional }\end{array}$} & \multicolumn{3}{|c|}{$\begin{array}{l}\text { Tested clones } \\
\text { Klon percobaan }\end{array}$} \\
\hline & $\mathrm{Na}$ & Но & $\mathrm{He}$ & $\mathrm{Na}$ & Ho & $\mathrm{He}$ & $\mathrm{Na}$ & Но & $\mathrm{He}$ \\
\hline mTcCIR7 & 3 & 0.375 & 0.586 & 3 & 0.08 & 0.53 & 4 & 0.52 & 0.69 \\
\hline mTcCIR6 & 6 & 0.375 & 0.695 & 7 & 0.92 & 0.69 & 5 & 0.68 & 0.66 \\
\hline mTcCIR22 & 4 & 0.250 & 0.656 & 3 & 0.50 & 0.49 & 5 & 0.64 & 0.54 \\
\hline mTcCIR24 & 3 & 0.286 & 0.439 & 4 & 0.50 & 0.60 & 6 & 0.26 & 0.68 \\
\hline mTcCIR8 & 6 & 0.500 & 0.734 & 3 & 0.42 & 0.54 & 5 & 0.54 & 0.70 \\
\hline mTcCIR1 & 5 & 0.250 & 0.680 & 2 & 0.67 & 0.50 & 2 & 0.52 & 0.50 \\
\hline mTcCIR11 & 6 & 0.500 & 0.773 & 7 & 0.58 & 0.67 & 6 & 0.64 & 0.70 \\
\hline mTcCIR12 & 7 & 0.500 & 0.828 & 5 & 1.00 & 0.69 & 8 & 0.80 & 0.77 \\
\hline mTcCIR15 & 8 & 0.625 & 0.797 & 9 & 0.75 & 0.83 & 10 & 0.76 & 0.83 \\
\hline mTcCIR37 & 8 & 0.500 & 0.828 & 9 & 0.55 & 0.80 & 10 & 0.68 & 0.83 \\
\hline mTcCIR33 & 11 & 0.875 & 0.891 & 10 & 0.67 & 0.75 & 10 & 0.72 & 0.86 \\
\hline mTcCIR18 & 6 & 0.750 & 0.805 & 7 & 0.75 & 0.70 & 8 & 0.88 & 0.82 \\
\hline mTcCIR26 & 7 & 0.571 & 0.816 & 5 & 0.42 & 0.73 & 7 & 0.64 & 0.74 \\
\hline mTcCIR40 & 10 & 0.750 & 0.875 & 5 & 0.42 & 0.59 & 5 & 0.48 & 0.53 \\
\hline mTcCIR60 & 5 & 0.37 & 0.64 & 7 & 0.83 & 0.69 & 7 & 0.68 & 0.78 \\
\hline Total & 95 & & & 86 & & & 98 & & \\
\hline Average (Rerata) & 6.33 & 0.49 & 0.74 & 5.73 & 0.60 & 0.65 & 6.53 & 0.63 & 0.71 \\
\hline
\end{tabular}

Note $($ Keterangan $): \mathrm{Na}=$ Number of alleles $($ jumlah allel $) ; \mathrm{Ho}=$ Observed heterozygosity $($ heterozigositas teramati $) ;$ He $=$ Expected heterozygosity (heterozigositas harapan).

tested clones $(\mathrm{He}=0.71)$ in equal number with international clones $(\mathrm{He}=0.74)$.

The tested clones performed high genetic diversity based on the value of observed heterozigosity ( $\mathrm{Ho}=0.63)$ compared to national clones $(\mathrm{Ho}=0.60)$ and international clones $(\mathrm{Ho}=0.49)$. The less value of Ho within international clones would be due to low number of accessions tested. By using similar method, it was also detected that Ho within Refractario collection in Ecuador was 0.55 (Zhang et al., 2008) whereas within Forastero collection in Brazil was 0.35 (Sereno et al., 2006). This results showed that Indonesian cocoa collection which were presented by tested clones and national clones performed high genetic diversity which was similar with the diversity of international collection.

The grouping based on genetic distance performed three clusters of genetic groups, namely Trinitario, Forastero and Criollo (Figure 2). The group of Trinitario refers to DR (Djati Roenggo) clones which were selected within Trinitario population from Venezuela in 1888 (van Hall, 1914) then well known as Java Criollo due to producing white beans as Criollo type. Susilo et al., (2011) also confirmed that DR clones grouped to Trinitario cluster. Of the national reference, ICCRI 02 performed close to the international reference of Criollo 22 then constructing a small group of Criollo cluster. The Forastero group refers to IMC 67 of the international collection belong to Forastero group (Smulders et al., 2008) which was also grouped as Upper Amazon (Lachenaud \& Oliver, 2005) then the Forastero group also refers to Ucayali-1 dan Huallaga-1 of the Peruvian clones which were grouped as Upper Amazon Forastero (Eskes et al., 2007). The tested clones performed so diverse of their genetic back- 


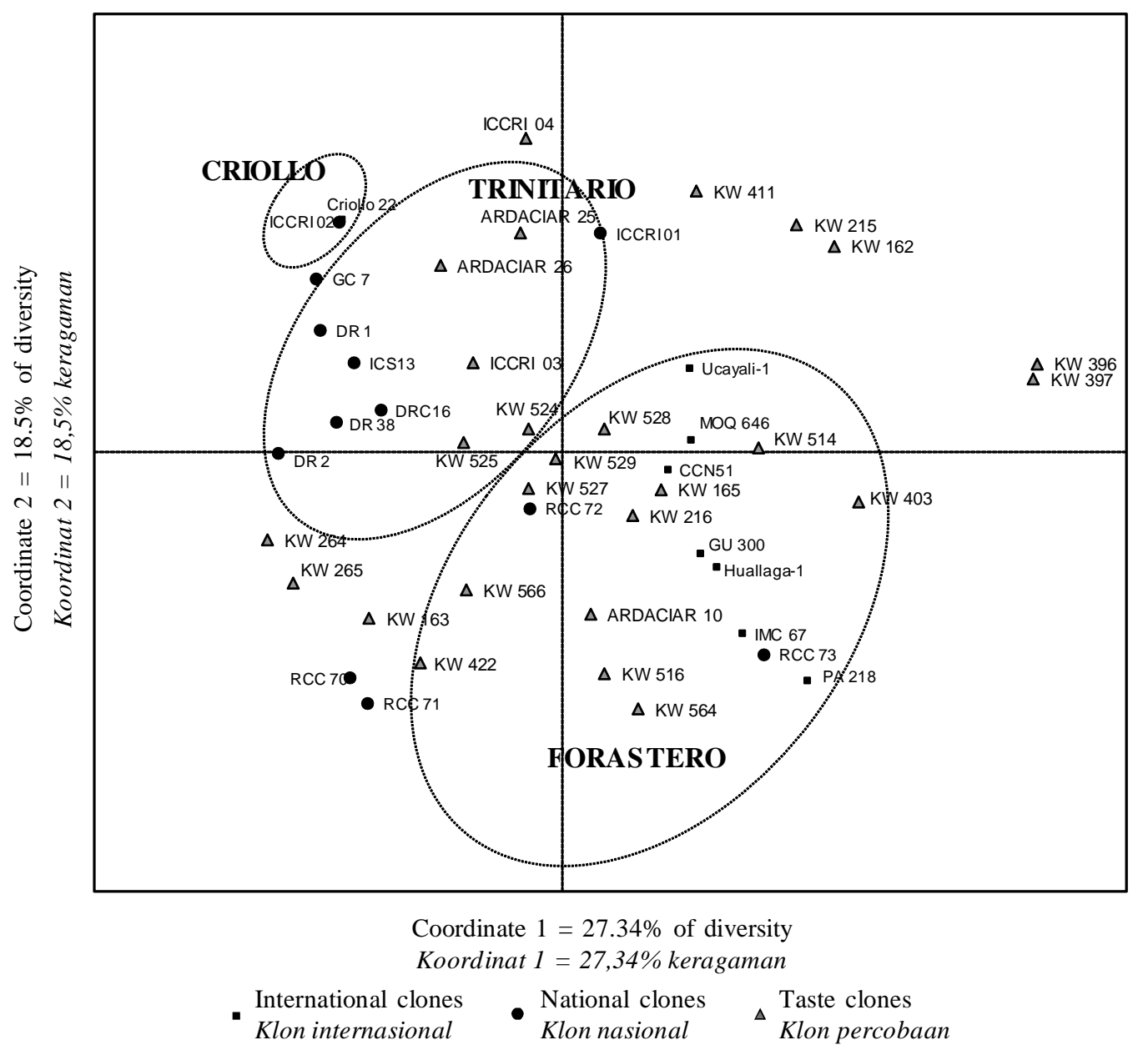

Figure 2. Scatter plot of principal coordinate analysis (PCoA) result in grouping the tested clones based on genetic distance by using 15 SSR primers.

Gambar 2. Diagram pencar hasil analisis koordinat untuk pengelompokan klon-klon materi percobaan berdasarkan jarak genetik hasil analisis dengan 15 pemarka SSR.

ground as most of the tested clones stood sparsely within two main clusters of Trinitario and Forastero. This study indicated that the selected CPB-resistant clones (ARDACIAR 10 and KW 397) belonged to different clusters in which ARDACIAR 10 belong to Forastero group compare to KW 397 which stand alone out of the two main clusters close proximity to KW 396. The out clusters of cocoa clones still could not be identified of their genetic group as no reference used in this study.
Furthermore breeding for CPB resistance will be designed by inter-crossing between selected-parental clones which perform differences on CPB resistance, yield potency and genetic background. The dendrogram graph (Figure 3) showed that ARDACIAR 10 of the resistant clones performed close relationship with the high yield clone of KW 30 (ICCRI 03) and KW 48 (ICCRI 04). Meanwhile, other resistant clone of KW 397 (Na 33) performed close relationship with other high yielding clone 


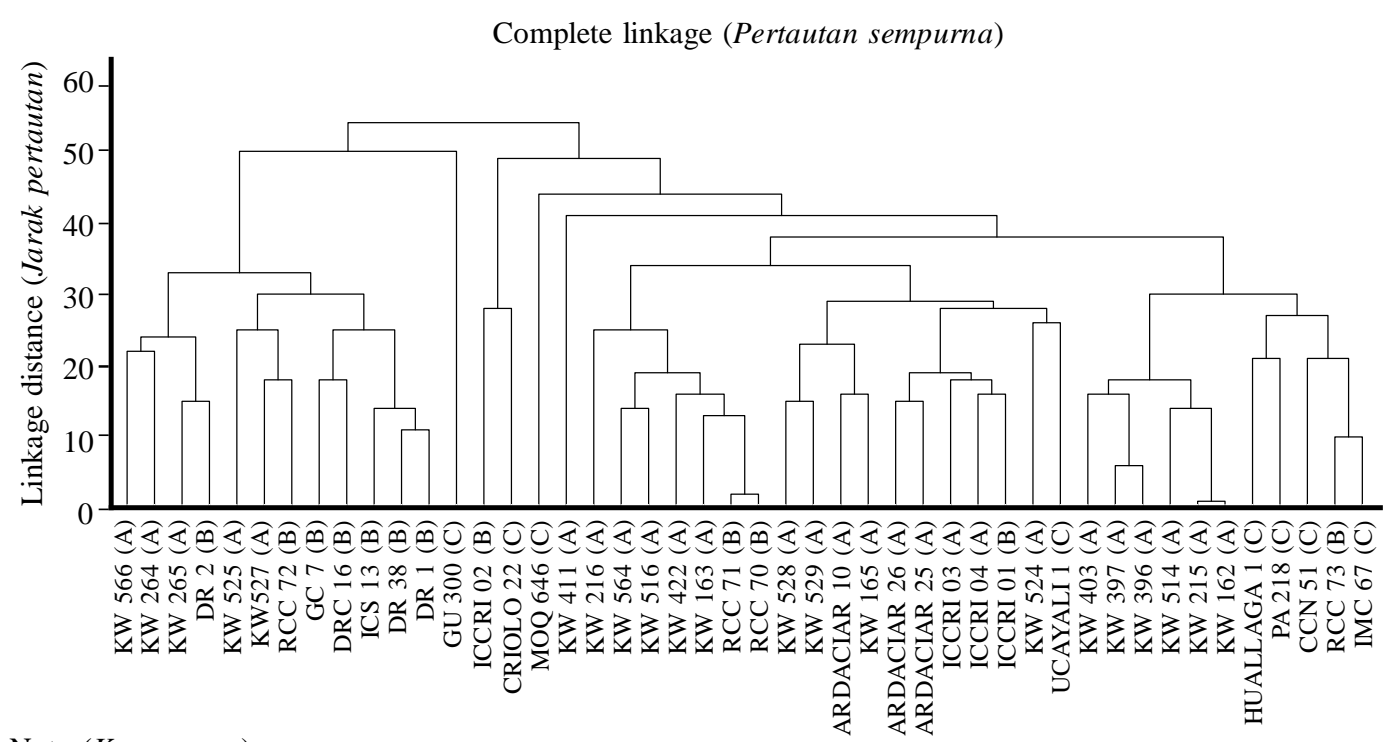

Note (Keterangan):

A. Tested clones (klon percobaan)

B. National clones (klon referensi nasional)

C. International clones (klon referensi internasional)

Figure 3. Dendrogram of genetic distance among the tested and the references clones based on DNA finger printing analysis by using 15 SSR primers.

Gambar 3. Dendrogram jarak genetik antar klon-klon materi percobaan dan klon-klon referensi berdasar hasil analisis sidik jari DNA dengan menggunakan 15 pemarka SSR.

of KW 162 (Sulawesi 01). Use of these criteria enable to develop the appropriate mating design among collected clones such as crosses between the resistant clone of ARDACIAR 10 with the high yield clone of KW 162 which both performed differences in their genetic background.

\section{CONCLUSIONS}

1. DNA fingerprinting on cocoa collections which are resistant to CPB performed high genetic diversity of the collections with the number of alleles was 98 (6.53 per locus) compared to international clones with the number of alleles was 95 (6.33 per locus). The observed heterozygosity (Ho) of the tested clones of 0.63 also indicate higher value compare to the international clones of 0.49 .
2. Cluster analysis of the tested clones based on genetic distance performed three main cluster groups, namely Trinitario, Forastero and Criollo in which the tested clones stand separately in the groups of Trinitario and Forastero. The CPB-resistant clones of ARDACIAR 10 and KW 397 indicated differences on their genetic background.

\section{REFERENCES}

Ditjenbun (2008). Pedoman Umum Gerakan Peningkatan Produksi dan Mutu Kakao Nasional 2009-2011. Departemen Pertanian, Direktorat Jenderal Perkebunan, Jakarta.

Eskes, A.B.; D. Guarda; L. Garcia \& R.P. Garcia (2007). Is genetic variation for sensory traits of cocoa pulp related to fine cocoa traits?. INGENIC Newsletter Issue, 11, December 2007. 
Lachaneud, P. \& G. Oliver (2005). Compatibility and duration of pod maturation in Guinian wild cocoa trees - preliminary results. INGENIC Newsletter, 10 , September 2005.

Lanaud, C.; A.M. Risterucci; I. Pieretti; M. Falque; A. Bouet \& P.J.L. Lagoda (1999). Isolation and characterization of microsatellites in Theobroma cacao L. Molecular Ecology, 8, 2141-2143.

Motilal, L.A.; D. Zhang; P. Umaharan; S. Mischke; M. Boccara \& S. Pinney (2009). Increasing accuracy and throughput in large-scale microsatellite fingerprinting of cacao field germplasm collections. Tropical Plant Biology, 2, 23-37.

Opoku, S.Y.; R. Bhattacharjee; M. KolesnikovaAllen; E.G. Asante; M.A. Dadzie \& Y. Adu-Ampomah (2009). Profile and genetic diversity of planting materials in Ghana cocoa farms. p. 61- 72. In: A.B. Eskes; Y. Efron; M.J. End \& F. Bekele (Eds.). International Workshop on Cocoa Breeding for Farmers' Needs in San José, Costa Rica. INGENIC and CATIE.

Peakall, R. \& P.E. Smouse (2006). Genalex 6: genetic analysis in Excel. Population genetic software for teaching and research. Molecular Ecology Notes, 6, 288-295.

Pokou, N.D.; J.A.K. N'Goran; A.B. Eskes; J-C. Motamayor; R. Schnell; M. Kolesnikova-Allen \& A. Sangaré (2006). Genetic diversity of selected cocoa (Theobroma cacao L.) in farmer's field in Côte-d'Ivoire. p. 53-60. In: A.B. Eskes; Y. Efron; M.J. End \& F. Bekele (Eds.). International Workshop on Cocoa Breeding for Farmers' Needs in San José, Costa Rica. INGENIC and CATIE.

Risterucci, A.M.; L. Grivet; J.A.K. N'Goran; I. Pieretti; M.H. Flament \& C. Lanaud (2000). A high-density linkage map of Theobroma cacao L. Theoretical and Applied Genetics, 101, 948-955.
Saunders, J.A.; S. Mischke; E.A. Leamy \& A.A. Hemeida (2004). Selection of international molecular standards for DNA fingerprinting of Theobroma cacao. Theoretical and Applied Genetics, 110, 41-47.

Sereno, M.L.; P.S.B. Albuquerque; R. Vencovsky \& A. Fiqueira (2006). Genetic diversity and natural population structure of cocoa (Theobroma cacao L.) from the Brazilian Amazon evaluated by microstellite markers. Conservation Genetics, 7, 13-24.

Smulders, M.J.M.; D. Esselink; F. Amores; G. Ramos; D.A. Sukha; D.R. Butler; B. Vosman \& E.N. van Loo (2008). Identification of cocoa (Theobroma cacao L.) varieties with different quality atributes and parentages analysis of their beans. INGENIC Newsletter Issue, 12 April 2008.

Susilo, A.W.; D. Zhang; L. Motilal; S. Mischke \& L.W. Meinhardt (2011). Assessing genetic diversity in Java fine-flavor cocoa (Theobroma cacao L.) germplasm by using simple sequence repeat (SSR) markers. Tropical Agriculture Development, 55, 84-92.

Susilo, A.W.; I. Anita-Sari; Sobadi; I Ketut Suwitra \& Nurlia (2012). Stabilitas dayahasil klon-klon harapan kakao (Theobroma cacao L.) tahan hama penggerek buah kakao (Conopomorpha cramerella Snell.). Pelita Perkebunan, 28, 123-135.

Susilo, A.W.; W. Mangoendidjojo; Witjaksono; E. Sulistyowati \& S. Mawardi (2009). Respons ketahanan beberapa klon kakao (Theobroma cacao L.) terhadap hama penggerek buah kakao (Conopomorpha cramerella Snell.). Pelita Perkebunan, 25, 161-173.

Urquhart, D.H. (1961). Cocoa. $2^{\text {nd }}$ edition, Longmans, $293 \mathrm{pp}$.

van Hall, C.J.J. (1914). Cocoa. MacMillan \& Co. Limited, London. p. 515.

Zhang, D.; S. Mischke; R. Goenaga; A. Hemeida Alaa \& J.A. Saunders (2006). Accuracy

PELITA PERKEBUNAN, Volume 29, Nomor 1, Edisi April 2013 
and reliability of high-throughput microsatellite genotyping for cocoa. Crop Science, 46, 2084-2092.

Zhang, D.; M. Boccara; L. Motilal; D.R. Butler; P. Umaharan; S. Mischke \&
L. Meinhardt (2008). Microsatellite variation and population structure in the "Refractario" cacao of Ecuador. Conservation Genetic, 9, 327-337. 